\title{
Role of Non-Governmental Organization in Achieving Good Governance in Kabupaten Karawang (Case Study: Forum Komunikasi Daerah Aliran Sungai Citarum Plus in Rehabilitation of the Citarum River)
}

\author{
Haura Atthahara ${ }^{1}$, Yunita Sriwahyuningsih ${ }^{2}$ \\ \{h.atthahara@gmail.com $\left.{ }^{1}\right\}$ \\ Universitas Singaperbangsa Karawang, Indonesia ${ }^{1,2}$
}

\begin{abstract}
Forum Komunikasi Daerah Aliran Sungai Citarum Plus shortened to FORKADASC + is a non-governmental organization focused on environmental issues. FORKADASC + is a non-governmental organization that initially focuses on the problems of the Citarum River. Various activities have been done by FORKADASC + to help restore the Citarum river ecosystem that has been damaged by people who do not care about the environment.This research uses Ralston's role theory with five indicators: identify local groups and tactics to meet local needs, mobilize and agitate for active efforts to pursue identified needs, formulate long- term activities to pursue long-term goals is more common, generating and mobilizing local or external resources for rural development activities, planning regulations and implementing activities. The results show that, Citarum Plus River Communications Forum Plus has performed its duty as a third sector institution that can contribute its thoughts to the government. FORKADASC + is capable of producing a program to oversee the citarum river and has become a regional policy, but it is unfortunate that in practice the local government has not been able to act decisively against the offending party.
\end{abstract}

Keywords: Roles; Non-Governmental Organizations; FORKADASC +, Good Governance

\section{Introduction}

Equity of public service quality is a challenge experienced by all countries and regions. There are various limitations of the bureaucracy that can not reach all the needs of society. Therefore, it can not just rely on what is done by the bureaucracy alone. According to Ouchi and Bryson in Dwiyanto, public services in a country can be fulfilled through three types of organizations namely bureaucracy, market mechanism, and non-governmental organizations (NGOs) [1]. Political interaction (daily life arrangement) has two main elements: the state sector and the market sector. Between the interaction spaces of the sector, there is a third sector, namely the work of civil society, in this case the non-governmental organizations (NGOs) that have characteristics not government institutions, not profitable, solid and sustainable, giving goodness to other elements with potential owned, and loving fellow human beings [2]. 
So NGOs have an expansionary character in covering unfilled space by government activities or market activities. The involvement of the third sector will be utilized for the delivery of public services involving certain values and traditions. Understanding these values and traditions will enable the involvement of social and religious organizations in the delivery of public services such as education and health, which will be easily explained. The need for certain types of education felt by a group of people and can not be met by the government bureaucracy. Forum Komunikasi Daerah Aliran Sungai Citarum Plus or better known as FORKADASC + is a communication forum between communities and other community institutions. The river basin is understood as a plain which is a unity with the river and its tributaries. Its function is to store, save, and drain water from rainfall to the lake or sea naturally. As a country that rich in biodiversity, including river ecosystems with its flora and fauna variety, Indonesia is richer with its rivers. There are approximately 5,590 main rivers and 65,017 tributaries in Indonesia. The main river reaches a length of 94,573 km with a watershed reaching $1,512,466 \mathrm{~km}^{2}$. But now the civilization is torn, the last twenty years water quality along the Citarum River increasingly decreased water quality caused by many factors. Factors affecting the change in water quality are, population growth, agriculture sector change into industry, non-regulation of the environment, the loss of public awareness, and weak law enforcement further confuse the water of the Citarum River. Now the Citarum River civilization that once became proof of the triumph of the Tarumanegara Kingdom and the Kingdom of Sunda Galuh was gradually experiencing the process of destruction with his own civilization. Citarum River is increasingly crushed and displaced up to the estuary if watershed management and river basin only continue to think about physical development, regardless of the socioeconomic, cultural and environmental aspects that accompany it.

FORKADASC + is a communication forum between communities and other social institutions. Initiated by SOG RESCUE and assisted SAR SAGARA and Yayasan Kita, Kita aims to synergize the three elements that are responsible for the damage to the Citarum River Basin, which is the state, corporation, and society.

\section{Method}

This research using descriptive method and using qualitative approach, data collection technique is done by triangulation (combination). According Moleong, qualitative method is research that is intended to understand the phenomenon of what is experienced by research subjects such as behavior, perception, motivation, action and others holistically and by way of descriptive in the form of words and language. In a special context that is natural and by utilizing various natural methods. Then triangulation (composite) technique checks the validity of data that utilizes something other than that data for checking purposes or as a comparison of that data[3]. Because this research uses descriptive method and qualitative research approach hence in this research will describe in more detail about how Role of NonGovernmental Organization FORKADASC + in realizing Good Governance in Kabupaten Karawang (Study Case: Forum Komunikasi Daerah Aliran Sungai Citarum in rehabilitation of Citarum River). Informants in this research are the Public Relations and Kominfo of FORKADASC +, Member of DPRD Commission C, Head of Environment and Sanitation Office of Karawang Regency, Environmental Activist and community around Citarum River Basin. 


\section{Result and Discussion}

Forum Komunikasi Daerah Aliran Sungai Citarum or better known as FORKADASC + is a communication forum between communities and other social institutions. Initiated by SOG RESCUE and assisted SAR SAGARA and Yayasan Kita Kita aims to synergize the three elements that are responsible for the damage to the Citarum River Basin, which is the state, corporation, and society.

When all leads to industry/corporations for Citarum damage, it is forgotten that, at the four points of the bridge across the Citarum river, every day no less than 1.4 tons of household waste enters the Citarum river. The habit of throwing garbage into the Citarum river, plus so much mounting garbage, because residents throw and pile household waste along the banks of the river Citarum has made Citarum as a dirty river and damaged ecosystem.

On the basis of the above, started by Yayasan Kita Kita, then supported by SOG Rescue, and SAG SAGARA who are very concerned about Citarum, created the idea of Citarum Declaration of Independence on 24 - 25 November 2012, with the aim of the three elements committed together without blame to work together to improve the river so that the citarum will be clean, improve the ecosystem together, simultaneously, and systematically. The declaration is not merely read out, signed and after it is completed, it is the first step towards real work in the field together with simultaneous and synergic programs until the achievement of the goals of the Citarum Declaration of Independence. Forum Komunikasi Daerah Aliran Sungai Citarum is a continuation of the Citarum Declaration of Independence to carry out concrete work to improve the condition of the Citarum watershed in the future.

In realizing harmonious cooperation between government, society and corporations in recreating sustainable citarum in framework of productivity and sustainable purpose for society karawang generally and citizen of Citarum watershed in particular, then made Five main program for Five years ahead are: (1) Citarum Recovery Sustainable, (2) Return of Water Catchment Function, (3) Conservation Campaign, (4) Data collection, River damage information, (5) Environmental Cadreization, these five main programs are integrated in the Save Our Citarum program.

The role of FORKADASC + in controlling pollution of the citarum river is very important, considering that the citarum river is a river that has given its usefulness since the time of the State Taruma Kingdom, and now needs a handling to restore the glory of the citarum river as before.In general, governance is defined as the quality of the relationship between the government and the communities it serves and protects, private sectors (private sector / business world), and society (community). Good governance of the public sector is defined as a process of good governance, by involving stakeholders to various economic activities, social politics, and the utilization of various resources such as natural resources, finance, and human for the interests of the people who carried out by adhering to the principle of equality, equality, efficiency, transparency and accountability.

Good in Good Governance contains two meanings: First, the value that upholds the desire or the will of the people and the value that can improve the ability of the people in achieving national goals, independence, sustainable development and social justice. Second, the functional aspect of an effective and efficient government in the performance of its duty to achieve that goal [4]. In this study, researchers used the theory of implementation of the role of Non-Governmental Organizations from Ralston which identifies the implementation of the role of NGOs can be done in 5 indicators [5]. These five indicators are to identify local groups and tactics to meet local needs, mobilize and agitate to actively pursue those identified needs, formulate long-term activities to pursue common long-term goals, generate and mobilize local 
resources or external to rural development activities, as well as regulations on the planning and implementation of activities. Of the five variables above researchers can see the extent to which NGOs run its role to achieve the goals and objectives are planned.

Below is a detailed explanation of the results of research that has been obtained by researchers. In identifying local groups and tactics to meet local needs FORKADASC + has identified the community by way of river drilling (observing the Citarum watershed and river banks, zoning the river into 3 categories), inviting the community to become a river supervisory team, involving other environmental activists to supporting activities related to the Citarum River, Citarum River Maping, proposing program to the government (Patrol River) Citarum river line.

In addition FORKADASC + mobilization and agitation by way of Campaign through social media, making Citarum Lovers, Clean Sunday Movement, planting activity and other activities to participate oversee the river citarum. Some of the above programs are real actions to expand the network in order to strengthen every action taken and to cultivate sympathy for the Citarum river.

In formulating long-term activities to pursue longer-term goals more common FORKADASC + has long-term planning such as increased cooperation with 48 villages directly crossed by Citarum watershed, encouraging 48 POS observations of Citarum Observation, encouraging joint water patrol, enlightenment, Citarum and surrounding areas, Citarum Lestari Recovery, Return of Watershed Functions, Conservation Campaigns, Data Collection, River damage and Environmental Cadence Information. Not all programs can be implemented, but one of the programs they have created has been successfully implemented and has been approved into a regional program.

Furthermore, in generating and mobilizing local or external resources for rural development activities FORKADASC + Inviting the community through rivers and involving communities and establishing environmental associations in the Citarum watershed and lastly the planning and implementation regulations of FORKADASC + Planning activities are made based on environmental sensitivity and Activities in the form of socialization, observation with direct involvement of the community and other communities.

\section{Conclusion}

Good governance allows for an alignment of roles between the three actors above. As in the capacity building of good governance, there is a so-called change in the distribution of authority that has occurred the distribution of authority that had accumulated in the center to be decentralized to the regions, communities, associations and various institutions in the community. This means that currently the government is not the only actors in decisionmaking, society and also the private sector also have the opportunity to be involved in decision-making. Therefore, to create good governance, NGO or Non-Governmental Organization (NGO) which has alignment to environment in this case FORKADASC + in revitalizing Citarum River.

\section{References}

[1] A. Dwiyanto, Mewujudkan Good Governance Melalui Pelayanan Publik. Yogyakarta: Gajah Mada University Press, 2005.

[2] I. Bastian, Akuntansi Untuk LSM dan Partai Politik. Jakarta: Erlangga, 2007.

[3] L. . Moleong, Metodologi Penelitian Kualitatif. Bandung: PT Remaja Rosdakarya, 
2011.

[4] Sedarmayanti, Sumber daya manusia dan produktivitas kerja. Bandung: Mandar Maju, 2001.

[5] L. H. Vu and K. Aberer, "A probabilistic framework for decentralized management of trust and quality," in In International Workshop on Cooperative Information A, 2007. 